\title{
PROGRAM EARLY AGRO EDUCATION PADA SISWA SEKOLAH DASAR UNTUK MEWUJUDKAN PROGRAM SUSTAINABLE AGRICULTURE
}

\author{
Nancy Oktyajati, Srie Julie Rachmawati \\ Fakultas Teknik, Sains dan Pertanian Universitas Islam Batik Surakarta, Jl. Agus Salim No.10, \\ Surakarta, Jawa Tengah 57147 \\ Email: oktyajati.nancy@gmail.com
}

\begin{abstract}
ABSTRAK
Program early agro education merupakan salah satu pembelajaran pertanian bagi anak-anak sejak dini. Program pengabdian ini diikuti oleh anak-anak siswa Madrasah Ibtida'iyah (MI) Hidayatul Insan kelas satu. Program pengabdian diawali dengan diskusi dengan pihak guru untuk merumuskan kurikulum muatan lokal agro schooling yang akan diterapkan di MI Hidayatul Insan. Program selanjutnya yaitu persiapan sarana dan prasarana edukasi untuk materi siswa kelas satu, kemudian memberikan pelatihan kepada anakanak untuk berkebun atau menanam mulai dari pembibitan, pengolahan tanah di pot yang kecil serta pelatihan untuk merawat tanaman. Tujuan dari kegiatan pengabdian ini adalah membuka wawasan anak-anak usia Sekolah Dasar tentang pertanian, sehingga muncul kecintaan mereka terhadap bidang pertanian. Luaran dari pengabdian masyarakat dengan program early agro education ini adalah Fakultas Teknik Sains dan Pertanian Universitas Islam Batik (UNIBA) Surakarta berkontribusi dengan bidang keilmuannya yaitu teknik, sain dan pertanian untuk mendukung program pemerintah yaitu sustainable agriculture atau pertanian yang berkelanjutan. Program early agro education melalui agro schooling menghasilkan empat kompetensi dasar yang dimiliki peserta didik yaitu pemahaman siswa tentang jenis-jenis tanaman, siswa memahami bagaimana tanaman bisa tumbuh, pemahaman akan proses perkecambahan, serta siswa mengenal tanaman-tanaman yang ada di Al Qur'an.
\end{abstract}

Katakunci: agro schooling, early agro education, pertanian, sustainable agriculture

\section{ABSTRACT}

The early agro education program is one of the agricultural lessons for children from an early age. This community service program was attended by first-grade students of Madrasah Ibtida'iyah (MI) Hidayatul Insan. The community service program begins with a discussion with the teacher to formulate a local content curriculum for agro schooling that will be applied at MI Hidayatul Insan. The next 
program is the preparation of educational facilities and infrastructure for first-grade students, then providing training to children in gardening or planting starting from nurseries, cultivating land in small pots, and training to care for plants. The purpose of this community service activity is to open up the knowledge of elementary school-age children about agriculture so that their love for agriculture will emerge. The output of community service with this early agro education program is that the Faculty of Science and Agriculture, Islamic University of Batik (UNIBA) Surakarta contributes to its scientific fields, namely engineering, science, and agriculture to support government programs, namely sustainable agriculture. The early agro education program through agro schooling produces four basic competencies that students have, namely students' understanding of plant types, students understanding how plants can grow, understanding the germination process, and students getting to know plants in the AlQur'an.

Keywords: agriculture, agro schooling, early agro education, sustainable agriculture

\section{PENDAHULUAN}

Pertanian merupakan sektor penting bagi manusia serta memiliki arti penting dalam pembangunan perekonomian bangsa Indonesia (Maulana, 2019). Namun minimnya petani muda di Indonesia menjadikan sektor pertanian menjadi terpinggirkan (Rahmawatiningsih et al., 2010). Krisis petani muda memiliki konsekuensi terhadap pembangunan sektor pertanian berkelanjutan (sustainable agriculture) (Carbone dan Subioli, 2012). Proses regenerasi petani diperlukan untuk menggantikan petani tua untuk mencegah penurunan jumlah petani (Pamungkaslara, 2017). Hadirnya petani baru akan memberikan energi baru dan akan meningkatkan profesionalisme pada sektor pertanian (Kontogeorgos et al., 2014). Hal ini dikarenakan petani muda cenderung lebih inovatif dan mudah menerima perubahan (Hamilton et al., 2015). Dukungan terhadap adanya petani muda akan meningkatkan daya saing bidang pertanian sebuah negara. Tujuan dari langkah ini adalah untuk meningkatkan produktivitas kepemilikan pertanian yang dipimpin oleh petani muda dan meningkatkan jumlah petani yang mulai mempraktikkan kegiatan pertanian untuk pertama kalinya (Marcu, 2014; Zagata \& Sutherland, 2015).

Pertanian merupakan sektor potensial untuk dikembangkan di Indonesia namun belum didukung oleh sumber daya manusia yang memadai. Fakta dilapangan menunjukkan sumber daya manusia bidang ini cenderung mengalami penurunan minat (degenerasi). Ketidakberlangsungan generasi petani akan berdampak pada perubahan organisai produksi pertanian dan berakibat pada pembangunan agraria (Joosse dan Grubbström 2017). Jumlah petani muda jauh lebih rendah dibanding petani tua (Anwarudin et al., 2018). Rendahnya minat serta persepsi negatif generasi muda Indonesia untuk menggeluti bidang pertanian saat ini boleh dikatakan sudah cukup memperihatinkan (Setiawan et al., 2015). Berdasarkan data BPS tahun 
2018 persentase petani berusia lebih dari 45 tahun $45 \%$, dan usia dibawah 35 tahun adalah 17 tahun (BPS, 2018). Kondisi itu telah disadari pemerintah. Karena itu, melalui Kementerian Pertanian (Kementan), pemerintah mengeluarkan SK Permentan No.7/Permentan / OT.140 / I /2013 tentang Pedoman Pengembangan Generasi Muda Pertanian. Tujuannya agar generasi muda bisa mengenal, mencintai dan berminat berusaha di bidang pertanian.

Proses penyuluhan serta pembinaan sejak dini generasi muda pada sektor pertanian akan akan menjadi proses awal dalam regenerasi pelaku pertanian (Anwarudin dan Haryanto 2018). Madrasah Ibtida'iyah Hidayatul Insan (MI HI) yang berada di bawah naungan Yayasan ADNAN, merupakan sekolah Madrasah Ibtida'iyah yang membentuk sistem pendidikan berkualitas, dengan orientasi pembentukan karakter peserta didik dengan menjadikan alam serta lingkungan sosial sebagai sumber utama media pembelajaran. Salah satu program unggulan MI Hidayatul Insan adalah mengenal dunia agriculture (pertanian, perikanan, dan peternakan). Penanaman pengetahuan agriculture ini bertujuan sebagai sarana untuk menanamkan karakter kemandirian sejak dini untuk siswa serta bentuk keprihatinan dari pihak yayasan akan rendahnya minat generasi muda terhadap dunia pertanian.

Salah satu Tri Dharma Perguruan Tinggi adalah pengabdian kepada masyarakat. Fakultas Teknik, Sains dan Pertanian, Universitas Islam Batik Surakarta bermaksud mengadakan program pengabdian kepada masyarakat dalam menjawab permasalahan krisis petani muda di Indonesia. Pengabdian kepada masyarakat merupakan hal yang wajib dilaksanakan di samping kegiatan pengajaran dan penelitian. Salah satu bentuk pengabdian kepada masyarakat yang dapat dilakukan adalah melalui kegiatan agro schooling (Warji, 2012). Agro schooling bertujuan untuk mengenalkan dunia pertanian dan lingkungan alam sekitar kepada siswa MI Hidayatul Insan, Karanganyar.

Minat generasi muda terhadap sektor pertanian perlu ditingkatkan melalui suatu metode pembelajaran aplikatif berbasis teknologi dibidang pertanian melalui praktek langsung (Ahmad dan Imam 2017). Agro schooling merupakan bentuk kegiatan untuk mengenalkan dunia pertanian pada anak-anak dalam pendidikan sekolah dasar. Metode pelaksanaan agro shooling adalah dengan lebih banyak melakukan praktik secara langsung mulai dari pembibitan, pengolahan tanah, hingga menanam. Siswa diberikan tanggung jawab untuk merawat dan memelihara tanaman hingga tanaman tersebut mampu bertahan hidup.

Pengenalan dunia pertanian jika dimulai di bangku perkuliahan sepertinya akan sangat terlambat. Generasi muda seharusnya mulai disadarkan akan pentingnya sektor pertanian sejak dini yaitu pada pendidikan dasar. Pendidikan pertanian sejak dini menjadi sesuatu yang esensial bagi suatu negara terlebih lagi bagi Indonesia yang merupakan negara agraris. Pendidikan pertanian harus diperkenalkan sejak dini kepada 
anak-anak. Perlu adanya penekanan bahwa ada berbagai macam sektor yang mampu membangun pertumbuhan ekonomi suatu negara dan pertanian adalah salah satu diantaranya.

Pemahaman sektor pertanian yang diberikan sejak dini akan mempermudah proses inovasi teknologi di bidang pertanian. Hal ini dikarenakan tingkat penerimaan terhadap inovasi teknologi akan lebih banyak mampu diterima oleh generasi muda. Saat ini penyuluh pertanian harus bersusah payah memberikan pendidikan teknis kepada petani yang sebagian besar berada di pelosok desa, berusia tua dan rendahnya pendidikan. Sumber daya manusia pada sektor pertanian sebagian besar tidak pernah mengenyam pendidikan teknis dasar atau tidak memahami pentingnya pendidikan pertanian (Muharamsyah, 2013).

Adanya program agro shooling ini akan meringankan beban penyuluh pertanian tanpa harus memberikan pemahaman dasar mengenai konsep pertanian berkelanjutan pada petani, jika mulai dari saat ini generasi muda kita, khususnya mereka yang ada di usia sekolah sudah mengetahui pentingnya sektor pertanian untuk pembangunan ekonomi lebih dini (Muharamsyah, 2013).

Tujuan dari program pengabdian masyarakat ini yaitu membantu pihak sekolah MI Hidayatul Insan Karanganyar untuk menyediakan media ajar untuk muatan lokal agro schooling yang menjadi salah satu program unggulan MI Hidayatul Insan serta meningkatkan keterampilan berpikir tentang pertanian kepada siswa MI Hidayatul Insan

\section{METODE}

Program agro education akan menjadi program unggulan dan menjadi kegiatan wajib di Sekolah. Kegiatan ini akan dimasukkan dalam kurikulum inti mata pelajaran siswa mulai dari kelas 1. Tahap awal kegiatan dimulai dengan diskusi bersama dengan pihak guru MI Hidayatul Insan dan yayasan ADNAN untuk perumusan kurikulum muatan lokal agro schooling. Perumusan kurikulum diawali dengan merumuskan timeline kegiatan pembelajaran. Timeline yang telah dirumusakan untuk siswa kelas satu terdiri atas 4 kompetensi dasar yaitu: Kompetensi Dasar I (KDI) Pemahaman anak tentang jenis-jenis tanaman, Kompetensi Dasar II (KDII) Pemahaman Mengapa tanaman bisa tumbuh?, Kompetensi Dasar III (KDIII) Perkecambahan, Kompetensi Dasar IV (KDIV) Pengenalan tanaman-tanaman yang ada di $\mathrm{Al}$ Qur'an. Masing masing kompetensi dasar dijadwalkan dapat dicapai dalam 3-4 pertemuan.

Tahap selanjutnya adalah persiapan alat edukasi yang akan digunakan sebagai media pembelajaran wawasan pertanian bagi siswa kelas 1. Persiapan awal adalah dengan pembelian buku-buku penunjang kegiatan penelitian. Buku ini yang akan dijadikan sebagai referensi dalam menyusun materi pembelajaran. Tahap persiapan alat terkait praktik pertanian dipersiapkan 
sesuai dengan tema atau materi yang diajarkan.

Tahap terakhir adalah pelaksanaan kegiatan pembelajaran agro education. Tahap pembelajaran dilakukan dengan tiga metode. Metode pertama yaitu pembelajaran dikelas dengan metode presentasi materi, menampilkan video atau poster. Metode kedua adalah praktik dilapangan, diawali dengan menerangkan cara praktik perkecambahan serta memberi tugas untuk mengamati pertumbuhan kecambah selama 1 minggu. Metode ke tiga adalah pemberian tugas menanam dan merawat tanaman dirumah dengan pendampingan dari orang tua. Tahap ini diawali dengan pembagian benih tanaman kepada semua siswa kemudian dijelaskan cara perawatan tanaman. Penilaian dilakukan dengan mengirimkan laporan via whatsapp terkait progres pertumbuhan tanaman secara periodik.

\section{HASIL DAN PEMBAHASAN}

\section{Gambaran Umum Analisis Situasi}

Madrasah Ibtida'iyah Hidayatul Insan (MI HI) yang berada di bawah naungan Yayasan ADNAN, beralamtkan di di Tegal Winangun, RT 02 RW 13 Tegalgede, Karanganyar. MI HI merupakan sekolah Madrasah Ibtida'iyah yang membentuk sistem pendidikan berkualitas, dengan orientasi pembentukan karakter peserta didik dengan menjadikan alam serta lingkungan sosial sebagai sumber utama media pembelajaran. Salah satu program unggulan MI Hidayatul insan adalah mengenal dunia agriculture (pertanian, perikanan, dan peternakan).

Permasalahan yang dihadapi oleh pihak sekolah untuk menerapkan program early agro education adalah :

1. Sekolah ini belum memiliki kurikulum untuk menerapkan muatan lokal agro schooling.

2. Sekolah belum memiliki sumber daya manusia yang secara spesifik menguasai bidang pertanian.

3. Sekolah belum memiliki sarana penunjang untuk kegiatan agro schooling.

Potensi penerapan program early agro education di MI Hidayatul Insan adalah:

1. Program early agro education telah sesuai dengan misi dan visi sekolah.

2. Sekolah telah memiliki lahan yang cukup luas yang dapat dimanfaatkan untuk menunjang kegiatan agro schooling.

\section{Pelaksanaan Program}

Luaran yang diharapkan dari pengabdian masyarakat dengan program early agro education ini adalah peningkatan penerapan iptek pada bidang agriculture pada pendidikan dasar. Dengan pengabdian ini Fakultas Teknik Sains dan Pertanian UNIBA mampu berkontribusi dengan bidang keilmuannya yaitu teknik, sain dan pertanian untuk mendukung program pemerintah yaitu sustainable agriculture atau pertanian yang berkelanjutan. Program early agro education ini diharapkan mampu mencetak generasi petani muda yang saat ini keberadaan nya semakin 
menurun sehingga mengancam ketahanan pangan. Kegiatan ini diawali dengan perumusan kurikulum muatan lokal agro schooling untuk pendidikan tingkat dasar.

Hasil pelaksanaan kegiatan pengabdian meliputi 3 tahap, yaitu:

a. Diskusi bersama dengan pihak guru MI Hidayatul Insan dan yayasan ADNAN untuk perumusan kurikulum muatan lokal agro schooling.

Kegiatan diskusi bersama pihak guru MI Hidayatul Insan dan yayasan ADNAN menghasilkan sebuah timeline pembelajaran mata pelajaran pertanian kelas 1. Kemudian dijabarkan dalam sebuah silabus pembelajaran mingguan.

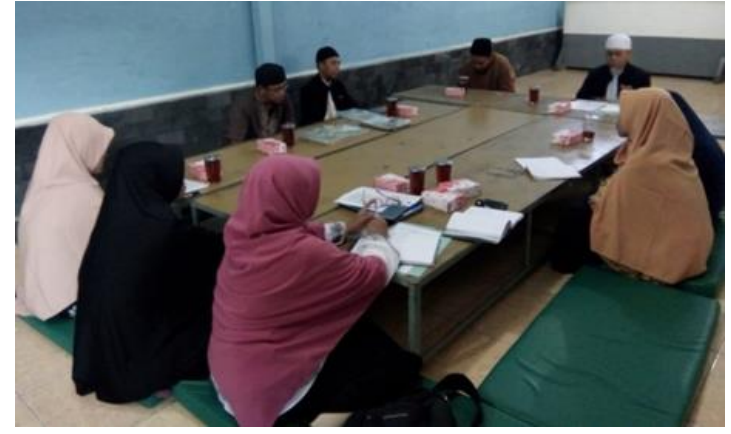

Gambar 1. Koordinasi Awal dan Penyusunan Timeline Pembelajaran

Program early agro education ini dilakukan mulai awal Juli 2019, yaitu diawali dengan diskusi penyusunan kurikulum. Kegiata selanjutnya dilakukan secara rutin satu minggu satu kali tatap muka dengan durasi waktu 2 x 35 menit per minggu.

Rencana kegiatan dirangkum dalam timeline pembelajaran selama 1 semester serta dilaporkan dalam jurnal proses belajar mengajar. Tabel 1 merupakan timeline rencana pembelajaran selama 1 semester:

Tabel 1. Timeline Pembelajaran Mata Pelajaran Pertanian Kelas 1 MIT Hidayatul Insan TA 2019/2020

\begin{tabular}{|c|c|c|c|}
\hline $\begin{array}{l}\text { Kompetensi } \\
\text { dasar }\end{array}$ & $\begin{array}{l}\text { Pertemuan } \\
\text { ke- }\end{array}$ & Materi & Praktek/Penugasan \\
\hline $\begin{array}{l}\text { KD 1: } \\
\text { Pemahaman } \\
\text { anak tentang } \\
\text { jenis-jenis } \\
\text { tanaman }\end{array}$ & $1-4$ & $\begin{array}{l}\text { Pendahuluan: } \\
\text { Pengenalan jenis-jenis } \\
\text { tanaman } \\
\text { - Tanaman Pangan } \\
\text { - Tanaman Sayuran } \\
\text { - Tanaman Buah } \\
\text { - Tanaman } \\
\text { perkebunan } \\
\text { - Tanaman rempah }\end{array}$ & $\begin{array}{l}\text { Pertemuan 1-4 membawa materi } \\
\text { powerpoint pertemuan ke2 } \\
\text { membawa media pembelajaran: } \\
\text { - Padi } \\
\text { - Kacang tanah } \\
\text { - Pertemuan ke-3 membawa } \\
\text { media ajar: } \\
\text { - Cabai } \\
\text { - Tomat } \\
\text { - Terong } \\
\text { - Pertemuan ke-4 media ajar } \\
\text { menunjukkan video hasil } \\
\text { perkebunan \& rempah }\end{array}$ \\
\hline $\begin{array}{l}\text { KD-2: } \\
\text { Pemahaman } \\
\text { Mengapa } \\
\text { tanaman bisa } \\
\text { tumbuh? }\end{array}$ & $5-6$ & $\begin{array}{l}\text { Tanaman bisa tumbuh } \\
\text { karena unsur-unsur } \\
\text { yang mendukung: } \\
\text { - Tanah } \\
\text { - Air } \\
\text { - Matahari }\end{array}$ & $\begin{array}{l}\text { Media ajar berupa video dan } \\
\text { powerpoint }\end{array}$ \\
\hline
\end{tabular}




\begin{tabular}{|c|c|c|c|}
\hline & & - Mikroorganisme & \\
\hline $\begin{array}{l}\text { KD-3: } \\
\text { Perkecambaha } \\
\text { n }\end{array}$ & $7-10$ & $\begin{array}{l}\text { Praktek materi } \\
\text { perkecambahan: } \\
\text { - Media tanah: cabai, } \\
\text { tomat, terong } \\
\text { - Media kapas: Kacang } \\
\text { hijau, kacang tanah } \\
\text { - Media Rockwol: } \\
\text { Kangkung, sawi } \\
\text { hijau }\end{array}$ & $\begin{array}{l}\text { Media ajar: } \\
\text { Pertemuan 7: } \\
\text { - Kapas } \\
\text { - Gelas air mineral } \\
\text { - Biji kacang hijau, kacang tanah } \\
\text { - Penugasan siswa: } \\
\text { - memelihara dan mengamati } \\
\text { petumbuhan } \\
\text { - Pertemuan 8: } \\
\text { - Rockwoll } \\
\text { - Nampan plastik } \\
\text { - Benih kangkung, sawi hijau } \\
\text { - Penugasan siswa: } \\
\text { - memelihara dan mengamati } \\
\text { petumbuhan } \\
\text { - Pertemuan 9: } \\
\text { - Tanah } \\
\text { - Polibag kecil } \\
\text { - Benih cabai, terong, tomat } \\
\text { - Pertemuan 10: } \\
\text { - Praktek pemindahan kecambah } \\
\text { yang tumbuh pada media tanam }\end{array}$ \\
\hline $\begin{array}{l}\text { KD-4 } \\
\text { Pengenalan } \\
\text { tanaman- } \\
\text { tanaman yang } \\
\text { ada di } \quad \text { Al } \\
\text { Qur'an }\end{array}$ & $11-13$ & $\begin{array}{l}\text { Pengenalan } 9 \text { tanaman } \\
\text { di dalam Al Qur'an: } \\
\text { tin, kurma, zaitun, } \\
\text { anggur, bawang, jahe, } \\
\text { delima, mentimun, } \\
\text { sayur-mayurnya, } \\
\text { kacang adasnya. }\end{array}$ & $\begin{array}{l}\text { Poster, powerpoint, buku } \\
\text { pendamping }\end{array}$ \\
\hline
\end{tabular}

b. Persiapan alat edukasi yang akan digunakan sebagai media pembelajaran wawasan pertanian bagi siswa kelas 1. Alat dan bahan yang dipersipakan dalam pengabdian terdiri atas :

1) Bahan pengajaran yang berupa materi presentasi dalam format powerpoint, format video, dan poster.

2) Bahan referensi mengajar: Berupa buku, poster

3) Bahan praktikum

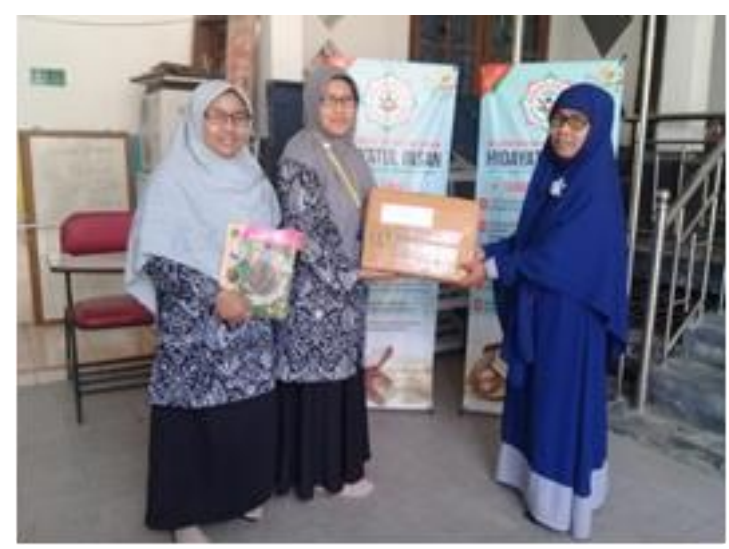

Gambar 2. Penyerahan Alat Edukasi Berupa Buku Sebagai Media Pengajaran 


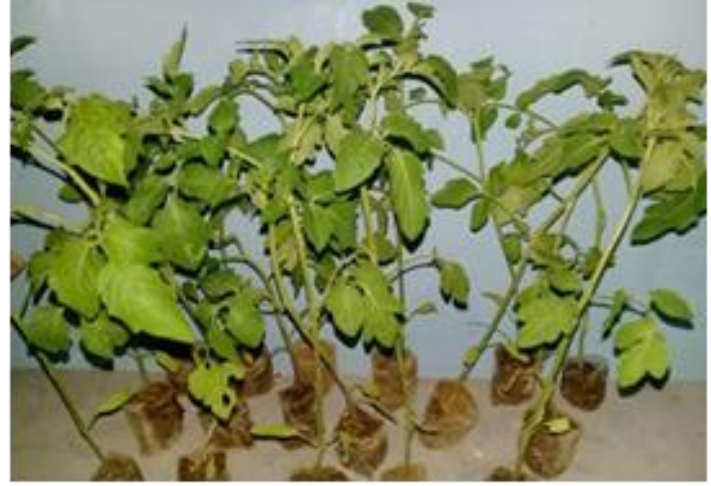

Gambar 3. Penyerahan Alat Edukasi Berupa Benih Tanaman Sebagai Media Pengajaran

c. Memberikan pelatihan kepada anak-anak untuk berkebun atau menanam mulai dari pembibitan, pengolahan tanah di pot yang kecil serta pelatihan untuk perawatan tanaman

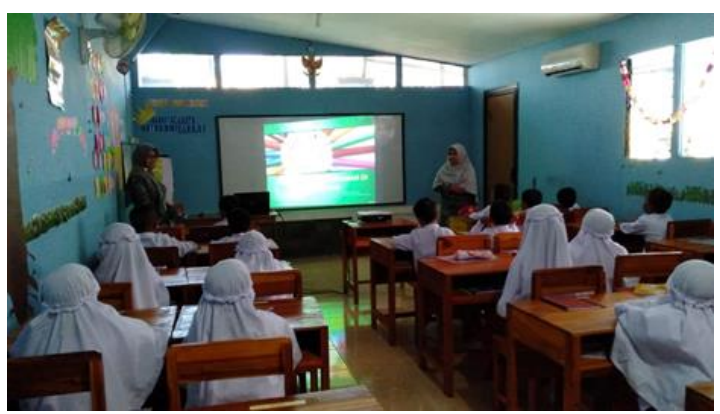

Gambar 4. Kegiatan Pembelajaran Pertanian di Kelas

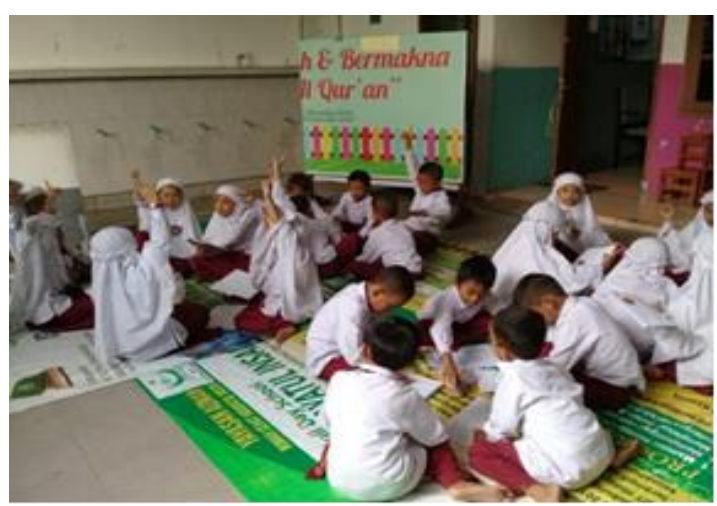

Gambar 5. Kegiatan Pembelajaran Mengenal Biji Tanaman

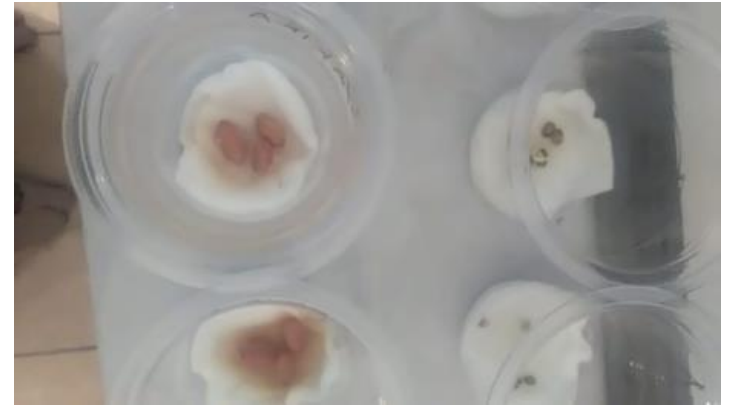

Gambar 6. Kegiatan Praktik Perkecambahan

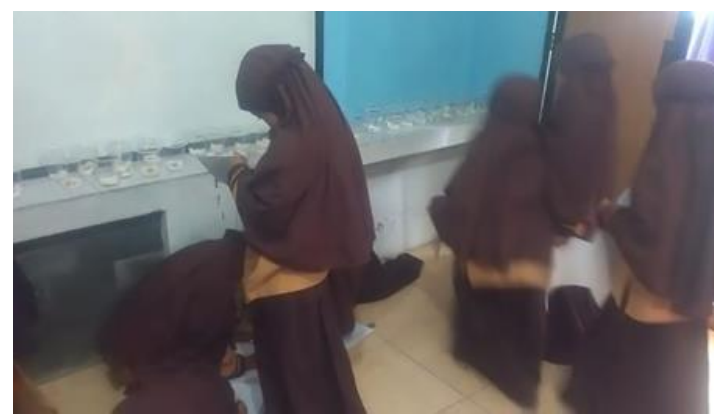

Gambar 7. Pengamatan Pertumbuhan Kecambah

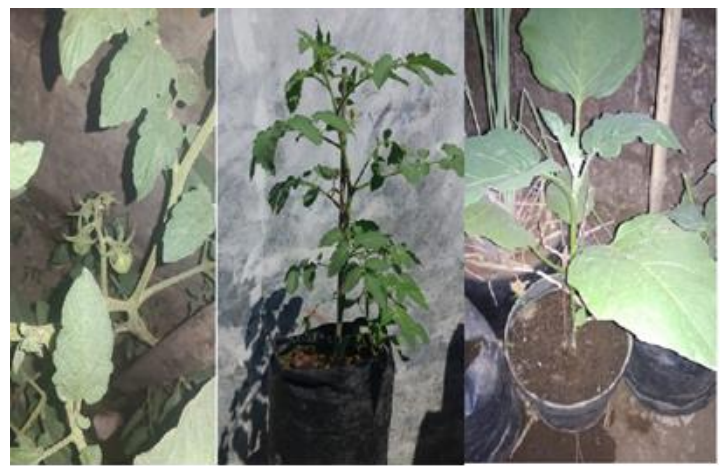

Gambar 8. Hasil Pembelajaran Menanam dan Merawat Tanaman

\section{KESIMPULAN}

Lesson learn yang didapat dalam proses pengabdian kepada masyarakat adalah penerapan Program Agro schooling pada MI Hidayatul Insan Karanganyar. Agro schooling bertujuan untuk mengenalkan dunia pertanian dan lingkungan alam sekitar kepada anakanak khusunya anak-anak sekolah dasar. Agro schooling dikemas dalam bentuk kegiatan yang beda, tidak 
formal, kratif dan inovatif sehingga anak-anak bisa bermain sambil belajar. Penerapan agro schooling pertama-tama anak-anak diajarkan tentang dunia pertanian melalui video unik pertanian bahkan yang dikemas dalam film kartun. Kemudian diajarkan juga proses menanam tanaman mulai dari awal hingga panen melalui gambargambar.

Anak-anak diajak langsung untuk berkebun atau menanam mulai dari pembibitan, pengolahan tanah di pot yang kecil, namun yang berbeda adalah pot mereka diberi nama mereka dan kelompok yang berbedabeda serta juga dikompetisikan sampai panen nanti mana yang rajin dalam merawat dan menyiram tanaman. Ini juga sederhana karena anak-anak akan mulai berkutat dengan tanah sehingga tidak takut kotor.

Kemudian selama anak-anak menunggu tanaman mereka tumbuh, mereka diajarkan juga pengetahuan alam yang mendukung pertumbuhan tanaman misalnya air dan microorganisme. Penanaman akidah juga dilakukan dengan memberikan materi keajaiban tanaman yang telah disebut dalam ayat suci. Hal ini akan menumbuhkan rasa menyayangi tanaman sebagai bentuk ibadah kepada Allah.

Pendidikan pertanian sejak dini akan mempermudah inovasi teknologi di bidang pertanian serta pemahaman dasar tentang konsep pertanian itu sendiri. Belajar di masa muda seperti mengukir di atas batu hal ini memberi penjelasan mengapa saat ini para penyuluh pertanian masih susah payah memberikan pendidikan teknis pada petani yang kebanyakan berada di pelosok desa di sentra pertanian, karena dahulu sumberdaya- sumberdaya manusia yang potensial ini tidak pernah mengenyam pendidikan teknis pertanian dasar itu, atau memang dulu kita belum sadar akan pentingnya pendidikan pertanian.

\section{DAFTAR PUSTAKA}

Anwarudin, O., Yoyon, H. (2018). The Role of Farmer-to-Farmer Extension as a Motivator for The Agriculture Young Generation. International Journal of Social Science and Economic Research, 03(01): 428-37.

Anwarudin, O., Arif S., Anna, F. (2018). A Review on Farmer Regeneration and Its Determining Factors in Indonesia. International Journal of Progressive Sciences and Technologies, 10(2): 218-30.

Rahmawatiningsih A., Prayoga, I.M.A., Yanthi, N.P.W., Temaja, I.G.R.M. (2010). Pemberian Ekstrakurikuler Pertanian Pada Siswa Sd Di Desa Gunaksa Kabupaten Klungkung, Bali. IPTEKMA, 2(1): 1-4.

BPS. (2018). Hasil Survei Pertanian Antar Sensus (SUTAS).

Carbone, A., and Giovanna S. (2012). The Generation Turnover in Agriculture: The Ageing Dynamics and the EU Support Policies to Young Farmers. The Common Agricultural Policy After the Fischler Reform: National Implementations, Impact Assessment and the Agenda for 
Future Reforms: 375-90.

Hamilton, W., Gary B., and Eric R. (2015). Entrepreneurial Younger Farmers and the Young Farmer Problem in England. The Journal Agriculture and Forestry, 61(4): 6169.

Joosse, S., and Ann G. (2017). Continuity in Farming - Not Just Family Business. Journal of Rural Studies 50: 198-208.

Kasdir M. (2019). Peran Kelompok Tani Terhadap Kondisi Perekonomian Petani. Jurnal Pendidikan Teknologi Pertanian, 5: 67-71.

Kontogeorgos, A. Anastasios M., Fotios C., and Eustratios L. (2014). New Farmers' a Crucial Parameter for the Greek Primary Sector: Assessments and Perceptions. Procedia Economics and Finance 14(14): 333-41. http:/ / dx.doi.org/10.1016/S2212 -5671(14)00721-7.

Marcu, A. (2014). Increasing Agricultural Competitiveness by the Setting up of Young Farmers. The Case of Moldavia, Romania. Journal of Settlements and Spatial Planning (3): 117-23.

Muharamsyah, H.A. (2013). Pendidikan Pertanian, Celah Kecil Menuju Pembangunan Yang Paripurna. International Association of Students in Agricultural and Related Sciences Local Committee Padjadjaran University.

Pamungkaslara, S.B. (2017). Regenerasi Petani Tanaman Pangan di Daerah Perkotaan Dan
Perdesaan Kabupaten Grobogan. Bumi Indonesia 6(3).

Setiawan, I., Sumardjo, P.T., and Arif S. (2015). Study of Role of Agribusiness Young Actors on Optimalization of Private Agricultural Extension in West Java Province, Indonesia Faculty of Agricultural Padjadjaran University. International Journal of Humanities and Social Science, 5(9): 161-69.

Thoriq A., Fauzan I. (2017). Edukasi Teknologi Pertanian untuk Anak Usia Dini di Desa Cilayung. Jurnal Aplikasi Ipteks untuk Masyarakat 6(1): 18-20.

Warji. (2012). Program Early Agroeducation Untuk Siswa Sekolah Dasar. Sakai Sambayan Jurnal Pengabdian kepada Masyarakat, 2(1): 54-60.

Zagata, L., and Lee A.S. (2015). Deconstructing the 'Young Farmer Problem in Europe': Towards a Research Agenda. Journal of Rural Studies 38(2015): 39-51.

http://dx.doi.org/10.1016/j.jrurs tud.2015.01.003. 